\title{
Conference on Religious Movements in Africa
}

A CONFERENCE on modern religious movements in Africa was held at Northwestern University from 8 to ro April, under the auspices of the African Studies Program of Northwestern University. It was convened by John Middleton (Northwestern University) and Victor Turner (Cornell University).

Participants included Ronald Cohen (Northwestern University), Elizabeth Colson (University of California at Berkeley), James Fernandez (Dartmouth College, who read a paper on 'Symbolic integration in Bwiti vernacular sermons'), Elizabeth Hopkins (Columbia University, ' The Nyabingi cult in south-western Uganda '), Igor Kopytoff (University of Pennsylvania, ' Problems of classification of religious movements'), John Middleton (Northwestern University), Robert Mitchell (Northwestern University), Marshall Murphree (University of London, 'The Shona Vapostori'), Ruth Simms (Northwestern University), George Simpson (Oberlin College, ' Religious movements in south-western Nigeria '), and Victor Turner (Cornell University, 'The waters of life: the roots of Zionist symbolism').

The conference made resolutions for the future study of religious movements in Africa, and decided that the papers presented should be included in a volume to be published on this subject. Plans were also made to compile and publish an annotated bibliography.

\section{Research Grants for African Studies}

THE Joint Committee on African Studies, sponsored by the American Council of Learned Societies, has made the following grants for research relating to Africa South of the Sahara:

Professor Elizabeth Colson (Berkeley, California): economic and political change among the Valley Tonga of Gwembe District.

Professor St. Clair Drake (Roosevelt University): urbanization in Ghana.

Professor James W. Fernandez (Dartmouth College): logical and aesthetic integration in the cult life of four contemporary African religious movements, in South Africa, Liberia, and Ivory Coast.

Mr. Robert Heussler (Oxford): British colonial government in the period preceding independence.

Professor Philip E. Leis (Brown University): political values and accommodation in the Federal Republic of Cameroon.

Professor Herbert S. Lewis (Wisconsin): leadership and community organization among the Galla of Ethiopia.

Professor Louis $R$. Molet (Montreal): religious phenomena in the 'Friday Year' ( 1965$)$ in the Malagasy Republic.

Professor Jan Vansina (Wisconsin): the history of the lower Kasai states.

Professor Hans Wolff (Northwestern): the Abua-Odual-Ogbia language group of the eastern Niger Delta.

\section{'Azania', Journal of the British Institute of History and Archaeology in East Africa}

THE British Institute of History and Archaeology in East Africa proposes to publish an annual journal, to be entitled Azania, the first number of which will, it is hoped, appear at the end of 1965 . The journal will be devoted to the 'pre-colonial' history and archaeology of eastern and central Africa (roughly between the parallels of $10^{\circ}$ North and $15^{\circ}$ South), and will contain articles (including short excavation reports) of between 4,000 and 10,000 words, with illustrations where appropriate. In addition, there will be a section of short notes and items of news, as well as book reviews, and it is hoped to include a list of current and proposed research activities, prepared in co-operation with the University of East Africa. The journal will be edited by Mr. H. N. Chittick, Director of the Institute. 